\author{
Evangelikal: Jurnal Teologi Injili dan Pembinaan Warga Jemaat \\ ISSN 2548-7868 (print), 2548-7558 (online) \\ Availabel at https://journal.sttsimpson.ac.id/index.php/EJTI/ \\ DOI: https://doi.org/10.46445/ejti.v5i2.378
}

\title{
Contextualization of the Bejopai Pattern of the Kubin Dayak Tribe as a Contextual Discipleship Effort in West Kalimantan
}

\author{
Susanto $^{1}$, Sabda Budiman ${ }^{2}$ \\ Sekolah Tinggi Teologi Simpson Ungaran, Jawa Tengah, Indonesia \\ Email: 'ragilsusanto007@gmail.com, 22sabdashow99@gmail.com
}

\begin{abstract}
Dayak Kubin tribe has a culture that still survives to this day, namely Bejopai culture. Bejopai is an activity of the Dayak Kubin community that is generally done by working in the areas. Through the Bejopai culture conducted by the Dayak Kubin tribe in West Kalimantan, the author observes that contextual discipleship can be done. The problem formulation in this study is how the purpose of this writing is how the contextual discipleship approach in Dayak Kubin tribe through Bejopai culture in West Kalimantan? The aim is to present the contextual discipleship approach in the Dayak Kubin tribe through Bejopai Culture in West Kalimantan. The qualitative research method using qualitative methods is to make observations, interviews, or study documents. The locus of this study is in Sungai Bakah Village. Through the discussion results, it was found that contextual discipleship can be applied through persuasive communication approaches, patterns of working while telling stories, and discipleship to discipleship. The conclusion is that Bejopai culture can be used as a medium to do contextual discipleship that is quite effective in the Dayak Kubin tribe.
\end{abstract}

Key Words: Bejopai culture, contextual discipleship, Dayak Kubin

\begin{abstract}
ABSTRAK: Suku Dayak Kubin memiliki budaya yang masih bertahan hingga saat ini yaitu budaya Bejopai. Bejopai ialah suatu aktivitas masyarakat Dayak Kubin yang umumnya dilakukan di ladang dengan bekerja di ladang bersama-sama. Melalui budaya Bejopai yang dilakukan oleh suku Dayak Kubin yang ada di Kalimantan Barat tersebut, penulis mengamati bahwa dapat dilakukan sebuah pemuridan secara kontekstual. Rumusan masalah dalam penelitian ini ialah bagaimana pendekatan pemuridan kontekstual dalam suku Dayak Kubin melalui budaya Bejopai di Desa Sungai Bakah? Tujuan dari penelitian ini ialah untuk memaparkan pendekatan pemuridan kontekstual dalam suku Dayak Kubin melalui Budaya Bejopai di Kalimantan Barat. Metode yang digunakan ialah metode penelitian kualitatif dengan melakukan pengamatan, wawancara, dan penelaahan dokumen. Penulis juga menggunakan pendekatan metode etnografi, dengan mengamati keseharian masyarakat Dayak Kubin yang berkaitan dengan aspek budaya masyarakat tersebut. Lokus dari penelitian ini yaitu di Desa Sungai Bakah. Melalui hasil pembahasan yang penulis lakukan, diketahui bahwa pemuridan kontekstual dapat diterapkan melalui pendekatan komunikasi persuasif, pola bekerja sambil bercerita, dan memuridkan untuk memuridkan. Kesimpulan dari penelitian ini ialah budaya Bejopai dapat dijadikan sebagai media untuk melakukan pemuridan secara kontekstual yang cukup efektif dalam konteks suku Dayak Kubin.
\end{abstract}

Kata Kunci : budaya Bejopai, pemuridan kontekstual, Dayak Kubin

Article History: Submitted: 3 Maret 2021

Revised: 13 Juni 2021

Published: 28 Juli 2021

\section{PENDAHULUAN}

Suku Dayak merupakan suku yang berasal dari pulau Kalimantan. Sebagian besar penduduk di Kalimantan beretnis Dayak. Istilah Dayak biasanya merujuk kepada orang-orang non-Muslim dan nonMelayu. Istilah Dayak diketahui muncul pada akhir abad kesembilan belas. Data dari Departemen Pen- didikan dan Kebudayaan Kalimantan Timur menjelaskan bahwa seorang ilmuwan Belanda yang bernama Dr. August Kaderland ialah orang pertama yang menggunakan istilah Dayak dalam konteks pendudukan kolonial pada tahun 1895 (Maunati, 2004, p. 65). Commans (1987, p. 6) juga mengartikan untuk arti kata dayak ialah orang yang tinggal di hulu 
sungai. King juga meneliti arti dari kata dayak yaitu berasal dari kata aja, sebuah kata sebutan dari bahasa Melayu yang berarti asli atau pribumi. Beberapa definisi tersebut menggambarkan atau mewakili karakteristik suku Dayak. Diperkirakan bahwa suku Dayak berasal dari Yunan di Cina Selatan, yang mana sekitar tahun 3000-1500 SM penduduk Yunan bermigrasi secara besar-besaran menuju Asia Tenggara, secara khusus ke Tumasik (Singapura) dan pulau Kalimantan (Pram, 2013, p. 50). Suku Dayak juga merupakan suku yang terdiri dari berbagai sub suku. Ukur mengatakan bahwa Dayak mempunyai sekitar 450 sub suku yang tersebar di seluruh daerah di Kalimantan (Maunati, 2004, p. 60). Secara garis besar, suku Dayak terbagi dalam enam rumpun besar, yaitu Apokayan (Kenyah-Kayan-Bahau), Ot Danum-Ngaju, Iban, Murut, Klementan, dan Punan. Rumpun suku yang diperkirakan paling tua ialah suku Dayak Punan (Pram, 2013, p. 50).

Suku Dayak Kubin merupakan salah satu di antara banyaknya sub suku Dayak. Suku Dayak Kubin dapat ditemukan di daerah Kabupaten Melawi, Kalimantan Barat. Penyebaran suku Dayak Kubin di Kabupaten Melawi mengarah ke selatan, yaitu di Kecamatan Pinoh Selatan. Dayak Kubin dapat ditemui antara lain di Desa Sungai Bakah, Desa Nyanggai, Desa Nanga Raya dan daerah di sekitarnya (Darmadi, 2017, p. 329). Susanto (2016, p. 1) menjelaskan bahwa suku Dayak Kubin merupakan clan dari suku Dayak Ot Danum yang juga merupakan penghuni dari Pulau Borneo bagian barat (Kalimantan Barat). Sebagaimana suku Dayak lainnya, suku Dayak Kubin juga masih memelihara berbagai budaya yang unik. Budaya merupakan suatu kebiasaan yang mencakup sistem dari prinsip, pola komunikasi, dan juga bentuk perilaku (Hesselgrave \& Rommen, 2015 , p. 200). Salah satu budaya yang masih terpelihara hingga saat ini dari suku Dayak Kubin ialah budaya Bejopai.

Bejopai adalah kegiatan yang dilakukan oleh sekelompok masyarakat Dayak Kubin dengan cara kerja bersama-sama atau gotong royong. Kegiatan Bejopai dalam suku Dayak Kubin umumnya dilaku- kan di ladang. Namun dalam kasus tertentu, masyarakat Dayak Kubin juga Bejopai dalam hal kerja membangun pondasi rumah dan sebagainya. Konsep dasar dari Bejopai ini juga dikenal di sub suku Dayak lainnya dengan istilah yang berbeda. Contohnya di Kalimantan Utara disebut dengan istilah Fezagenj Vempeng, Ngekem Feruyung dan di suku Dayak Keninjal disebut dengan istilah Sentalau (Harming, 2017, p. 51). Adat kebiasaan Bejopai masih dapat dijumpai dalam kehidupan sosial suku Dayak Kubin di Desa Sungai Bakah saat ini. Masyarakat Dayak Kubin masih mengedepankan kerja sama dan saling menolong satu dengan yang lain yang nampak dari budaya Bejopai tersebut.

Di dalam penelitian sebelumnya, Yusriadi et al. (2018) meneliti tentang suku Dayak Kebahan yang melalui pendekatan budaya Ngawa dan Bejopai, menjadikan suku Dayak Kebahan sebagai pendamai atau penengah antar suku yang ada di Kabupaten Melawi. Selanjutnya Herwinesastra (2019) pada tahun 2019 meneliti tentang budaya Betangkant Anak sebagai upaya kontekstualisasi pemahaman bahwa Allah telah mengasihi manusia berdosa dan mengangkatnya menjadi anak-Nya. Kemudian Gulo et al. (2019) meneliti tentang kontekstualisasi budaya di Dusun Gun Jemak-Kalbar sebagai sebuah misi. Dalam penelitian ini, Gulo et al. (2019) membahas tentang budaya Mabak-Sabak sebagai wadah kontekstualisasi pembinaan orang percaya di Dusun Gun Jemak, Kalimantan Barat.

Kebiasaan Bejopai dalam masyarakat Dayak Kubin di Desa Sungai Bakah ini yang kemudian menarik perhatian penulis untuk membahasnya. Meninjau dari penelitian sebelumnya yang mana ketiga penelitian tersebut membahas topik tentang budaya namun implikasi yang berbeda. Yusriadi et al. (2018) melihat budaya Ngawa dan Bejopai dalam suku Dayak Kebahan sebagai objek atau aktivitas untuk menjadikan suku tersebut pendamai atau penengah terhadap suku lainnya; Herwinesastra (2019) membahas budaya Betangkant Anak sebagai pendekatan kontekstual pengajaran tentang kasih Allah yang mengangkat orang berdosa jadi anak-Nya; Gulo et al. 
(2019) melihat budaya Mabak Sabek sebagai kontekstualisasi pembinaan umat.

Perbedaan penelitian ini dari ketiga penelitian sebelumnya yaitu penulis meneliti budaya Bejopai yang kemudian digunakan sebagai pendekatan pemuridan kontekstual. Mengingat bahwa sebagian besar masyarakat Dayak Kubin banyak menghabiskan waktunya di ladang sehingga sedikit waktu bagi masyarakat Dayak Kubin untuk berinteraksi dengan satu dengan yang lain dan sebagian besar waktunya digunakan untuk bekerja di ladang. Bejopai menjadi aktivitas yang memberikan ruang dan waktu yang cukup banyak bagi sesama masyarakat Dayak Kubin untuk berinteraksi. Melihat peluang tersebut, penulis ingin memaparkan pola pemuridan melalui budaya Bejopai. Ini juga dapat menjadi asupan rohani tambahan karena tidak semua masyarakat Dayak Kubin dapat mengikuti persekutuan yang diadakan oleh gereja setempat, mengingat keletihan saat bekerja, sehingga masyarakat Dayak Kubin sebagian besar hanya mengikuti ibadah Minggu Raya sebagai waktu pemuridan. Dalam penelitian ini, penulis meneliti budaya Bejopai di Desa Sungai Bakah.

Berdasarkan uraian dari latar belakang di atas, maka penulis merumuskan masalah sebagai berikut: "Bagaimana pendekatan pemuridan kontekstual dalam suku Dayak Kubin melalui budaya Bejopai di Desa Sungai Bakah? Adapun tujuan dari penelitian ini ialah untuk memaparkan pendekatan pemuridan kontekstual dalam suku Dayak Kubin melalui Budaya Bejopai di Desa Sungai Bakah.

\section{METODE}

Metode penelitian yang digunakan dalam penelitian ini ialah metode penelitian kualitatif. Moleong (2018, p. 9) mengatakan bahwa penelitian kualitatif menggunakan metode kualitatif ialah dengan melakukan pengamatan, wawancara, atau penelaahan dokumen. Penulis juga menggunakan pendekatan metode etnografi. Pendekatan etnografi ialah penelitian yang berupaya mengamati keseharian masyarakat tertentu yang berkaitan dengan aspek budaya masyarakat tersebut (Tanjung, Ritonga, \& Siregar,
2021, p. 92). Dalam hal ini, penulis melakukan pengamatan dan wawancara. Pengamatan dilakukan oleh penulis karena penulis merupakan bagian dari suku Dayak Kubin. Sedangkan wawancara dilakukan untuk mengumpulkan informasi yang lebih mendalam. Penulis juga melakukan wawancara dengan pendekatan petunjuk umum. Pendekatan petunjuk umum wawancara ialah dengan membuat kerangka namun tidak ada perangkat pertanyaan baku (Moleong, 2018, p. 187).

Penulis menggunakan pendekatan kontekstual C.L. Colen secara khusus tentang pendekatan yang bersifat kultural (Halim, 2000, p. 38-40). Pemberitaan Injil perlu dilakukan secara holistik. Artinya bahwa pemberitaan tersebut perlu mencakup kehidupan sosial, ekonomi, politik, dan terutama budaya. Pemberitaan Injil seharusnya masuk dalam kehidupan masyarakat. Dimana pun seorang pelayan berada, Injil perlu diberitakan, bahkan saat membajak sawah sekalipun (Halim, 2000, p. 40). Oleh karena itu, penulis menerapkan upaya pemuridan kontekstual berdasarkan cara pelaksanaan budaya Bejopai.

\section{HASIL DAN PEMBAHASAN}

\section{Deskripsi Sekilas Desa Sungai Bakah}

Desa Sungai Bakah merupakan desa kecil yang berada di kecamatan Pinoh Selatan, kabupaten Melawi, Kalimantan Barat. Menurut data dari Badan Pusat Statistik Kabupaten Melawi pada tanggal 5 November 2015, jumlah penduduk desa tersebut yaitu 616 jiwa dengan jumlah jiwa laki-laki 316 dan perempuan 300 jiwa (Badan Pusat Statistik Kabupaten Melawi, 2015, p. 10 Januari 2021, pukul 18:35). Masyarakat yang tinggal di Desa Sungai Bakah sebagian besar adalah orang Dayak Kubin dengan persentase $99 \%$ beragama Kristen. Desa Sungai Bakah berbatasan langsung dengan Desa Nyanggai (hulu) dan Desa Landau Garong (hilir). Di sepanjang pinggir Desa Sungai Bakah, mengalir suatu sungai yang bernama Sungai Mangat.

Mayoritas penduduk Desa Sungai Bakah bekerja sebagai petani karet. Selain bekerja menyadap 
karet setiap hari, masyarakat Desa Sungai Bakah juga bekerja di ladang pribadi. Hutan tropis yang cukup luas memungkinkan masyarakat Desa Sungai Bakah untuk berladang berpindah-pindah. Kebiasaan tersebut merupakan budaya yang telah diturunkan oleh nenek moyang suku Dayak. Akses internet di desa ini sangat minim sekali. Masyarakat hanya bisa menggunakan telepon biasa dan short message service (SMS) untuk berkomunikasi lewat telepon seluler. Selain akses internet yang tidak tersedia, infrastruktur di Desa Sungai Bakah juga dikategorikan minim. Jembatan menuju desa yang rusak serta jalan yang tergolong rusak membuat akses ke Desa Sungai Bakah cukup sulit. Akan tetapi, pada tahun 2018, akses listrik ke desa tersebut telah masuk dan itu bermanfaat sekali bagi kehidupan masyarakat di Desa Sungai Bakah.

\section{Pelaksanaan Bejopai dalam Suku Dayak Kubin}

Masyarakat Dayak Kubin masih memegang erat budaya Bejopai hingga saat ini. Budaya ini juga dikenal dengan istilah gotong-royong, namun dalam penerapannya berbeda dengan pemahaman gotongroyong pada umumnya. Dalam wawancara penulis kepada Firman (2021) yaitu salah satu pemuda Desa Sungai Bakah, melalui media komunikasi WhatsApp tentang Bejopai. Ia mengatakan bahwa Bejopai merupakan suatu kegiatan gotong-royong dengan konsep saling menguntungkan. Bejopai merupakan suatu budaya yang praktis dengan melakukan pekerjaan bersama di ladang seseorang. Akan tetapi, dalam kasus tertentu Bejopai juga dapat dilaksanakan tidak hanya di ladang, tetapi juga dapat dilakukan dengan kegiatan gotong royong lainnya seperti membangun rumah dan sebagainya, tergantung dari pihak yang melaksanakan kegiatan Bejopai tersebut yang juga dikenal dengan istilah Maik.

Istilah Maik dalam suku Dayak Kubin berkaitan erat dengan budaya Bejopai. Istilah Maik jika diartikan yaitu sebagai orang yang melaksanakan kegiatan Bejopai atau tuan rumah Bejopai. Jadi sederhananya ialah seperti seorang yang mengadakan pesta pernikahan yang disebut sebagai Tuan Rumah, begitu pula istilah Maik dalam konteks Bejopai.
Contoh penggunaan istilah Maik dalam bahasa Dayak Kubin ialah sebagai berikut: "sapai maik ari tuk? Aku obuk maik" yang artinya adalah "siapa yang membawa/jadi tuan rumah Bejopai hari ini? Saya besok jadi tuan rumah Bejopai." Jadi, jika si A yang Maik, itu berarti Bejopai dilakukan di ladang si A.

Dengan demikian, pelaksanaan Bejopai merupakan kegiatan yang umumnya dilakukan di ladang. Pelaksanaannya dilakukan secara bergiliran antara ladang yang satu dengan ladang yang lain secara bersama-sama. Penentuan untuk menjadi tuan rumah kegiatan Bejopai tidak terstruktur dan ditetapkan bersama saat Bejopai berlangsung.

\section{Waktu Bejopai}

Pelaksanaan Bejopai hampir dilakukan setiap hari baik setengah hari maupun satu hari penuh, kecuali hari Minggu dan juga tergantung dari pihak yang Maik. Bejopai juga dilakukan dengan bergiliran di setiap harinya, tergantung kesepakatan bersama pada saat istirahat makan siang ataupun pada saat istirahat minum kopi. Menurut Yusriadi et al. (2018, p. 22), Bejopai dilaksanakan pada jam 9 pagi dalam istirahat makan siang pada jam 12 siang dan dilanjutkan pada jam 1 siang sampai jam 4 bahkan 5 sore. Namun ada pengecualian dengan kegiatan Bejopai dengan tahap Nunu (bakar ladang). Nunu dilakukan selalu pada sore menjelang malam atau pada saat malam hari. Hal tersebut mengantisipasi penyebaran api ke wilayah hutan yang tidak termasuk dalam lokasi ladang.

\section{Ngari}

Budaya Bejopai diibaratkan dengan kegiatan yang mengandung makna tabur-tuai. Dikatakan demikian karena pihak yang terlibat dalam pelaksanaan Bejopai akan membalas di hari atau minggu berikutnya untuk ikut pelaksanaan Bejopai pada pihak yang sebelumnya mengadakannya. Pelaksanaan tersebut disebut dengan istilah ngari. Kata ngari digunakan bagi seseorang yang hendak mengikuti kegiatan Bejopai yang diadakan oleh pihak tertentu. Ngari sehari dibalas kerja sehari pula. Ngari dilaku- 
kan oleh perindividu. Tindakan Ngari juga dapat diwakili oleh orang lain. Selain itu, dalam proses pembalasan ngari juga dapat diwakili oleh orang lain juga. Salah satu contohnya ialah si A mengajak masyarakat untuk Bejopai di ladangnya (Maik) dan si B ingin Ngari si A, namun si B tidak dapat mengikuti Bejopai pada waktu itu dikarenakan ada urusan lain. Si B dapat menyuruh kerabat dekat atau kenalan untuk mewakili si B dalam Bejopai di ladang si A. Begitu pun saat dilakukan proses membalas Ngari dapat diwakili oleh orang lain. Namun saat ini, orang yang Ngari juga dapat dibayar dengan uang. Pada saat seseorang Bejopai di ladang orang yang Maik, orang yang Bejopai tersebut dapat dibayar dengan uang. Jika ia Bejopai hanya setengah hari (08:00-12:00), ia dibayar dengan bayaran sebesar Rp. 35.000, sedangkan jika ia Bejopai satu hari penuh (08:00-17:00), ia dibayar sebesar Rp 70.000. Orang yang Bejopai tersebut disebut sebagai orang upahan dan bukan orang yang Ngari. Jadi Ngari ialah tindakan membantu seseorang dengan tujuan akan dibantu pada hari/waktu berikutnya.

\section{Tahap-Tahap dalam Bejopai}

Dalam proses pembuatan ladang, ada beberapa tahap yang dilakukan masyarakat Dayak Kubin dalam Bejopai sehingga dapat menghasilkan hasil ladang yang siap dipanen. Tahap-tahap dalam Bejopai dilakukan secara berurutan dan terus-menerus diulang dalam satu tahun. Biasanya masyarakat Dayak Kubin memulai Bejopai dari tahap pertama pada bulan Agustus hingga menuai pada bulan Mei hingga Juni. Berikut tahap-tahap dalam pelaksanaan Bejopai dalam suku Dayak Kubin di Desa Sungai Bakah.

\section{Nobang}

Tahap pertama Nobang. Di dalam kegiatan Bejopai, hal pertama yang dilakukan ialah Nobang. Kegiatan Nobang dilakukan dengan memilih suatu lokasi yang luasnya $1 \frac{1}{2}$ hektar hingga 3 hektar untuk dijadikan lahan pertanian. Setelah mendapat lokasi untuk dijadikan lahan pertanian, selanjutnya dilakukan penebangan hutan guna mempersiapkan lahan tersebut sebagai lahan yang siap untuk diolah dalam proses selanjutnya. Kegiatan nobang biasanya dilakukan 2 hingga 3 kali kegiatan Bejopai. Adapun alat yang digunakan dalam pekerjaan Nobang ialah sensor, parang, dan beliung.

\section{Meladang}

Tahap kedua Meladang. Kegiatan meladang ini dilakukan untuk mempersiapkan pada tahap berikutnya, yaitu пипи. Proses pelaksanaannya yaitu dengan membersihkan sekeliling tepi lokasi yang telah disiapkan agar saat membakar setiap popohonan yang telah ditebang tidak terkena pepohonan di luar lokasi tersebut. Proses meladang juga sangat penting, karena jika tidak dilakukan dengan baik maka akan dapat menyebabkan kebakaran hutan. Proses Meladang juga dapat terbilang cukup lama. Dua hingga tiga kali kegiatan Bejopai dilakukan di suatu tempat hingga selesai, tergantung besar ladang tersebut dan berapa banyak orang yang ikut bekerja. Pekerjaan Meladang juga dilakukan dengan alat bantu cangkul, linggis dan parang.

Nunu

Tahap ketiga Nunu. Dalam bahasa Indonesia Nunu disebut "bakar". Jadi dalam Bejopai terdapat proses membakar hutan yang telah dipersiapkan untuk dijadikan ladang. Kegiatan Nunu biasanya dilakukan pada saat tiga hingga lima hari tidak mengalami hujan. Hal tersebut mengantisipasi ketidakmerataan saat pembakaran dilakukan. Kegiatan Nunu juga dilakukan pada waktu malam. Proses ini merupakan proses yang cukup berat dan berbahaya karena rentan terjadinya kebakaran hutan. Tujuan dari Nunu ialah agar tanah menjadi subur sehingga menghasilkan hasil bumi yang banyak.

\section{Meruguk}

Tahap keempat Meruguk. Meruguk ialah suatu kegiatan Bejopai yang melakukan pengumpulan batang-batang pohon yang telah dibakar dan tidak menjadi abu atau dengan kata lain masih berbentuk pohon arang. Arang-arang yang masih berbentuk ba- 
tang pohon tersebut dikumpulkan di berbagai tempat untuk dibakar ulang. Meruguk juga merupakan kegiatan merapikan untuk mempersiapkan tempat yang siap ditaburi benih. Selain itu, dalam pelaksanaan Meruguk, kaum pejopai juga memilih batang pohon yang panjang dan agak lurus untuk dibuat menjadi tanda jalan. Tanda jalan ini dibuat sebesar sekitar 1.5 hingga 2 meter. Tanda jalan ini juga menjadi batas kaum pejopai untuk menanam benih padi, ketan, maupun jagung.

Nugal

Tahap kelima Nugal. Setelah ladang selesai dibersihkan dan dirapikan, tahap selanjutnya yang dilakukan ialah Nugal. Nugal ialah kegiatan menaburi benih. Sebagian besar benih yang ditabur ialah benih padi. Namun biasanya selain padi, benih beras ketan dan benih jagung juga ditaburi di ladang. Ketiga benih tersebut tidak ditaburi secara acak, tetapi ditaburi dengan memilih lokasi yang berbeda. Biasanya kaum pria melubangi tanah dengan tongkat yang sengaja dilancipkan dan kaum wanita mengikuti dari belakang untuk menaburi benih di dalam lubang tersebut. Hasil wawancara yang dilakukan oleh penulis kepada salah satu masyarakat murni suku Dayak Kubin yang aktif dalam kegiatan Bejopai bernama Terisia, ia mengatakan bahwa Nugal dilakukan dari sebelah kanan ke kiri ladang dengan patokan depan ialah menghadap bukit atau pun hilir. Tujuannya ialah agar kegiatan Nugal cepat selesai dengan pemahaman bahwa jika dari kanan ke kiri maka kaki kiri yang terlebih dahulu melangkah (Amit, 2020).

Mabau

Tahap keenam Mabau. Mabau ialah kegiatan membersihkan gulma-gulma yang ada di sekitar tanaman di ladang. Kegiatan ini dilakukan setelah sebulan atau lebih dihitung sejak kegiatan Nugal selesai. Dalam jangka waktu sebulan lebih itu juga dapat dipastikan bahwa benih yang ditaburkan telah tumbuh. Mabau juga dilakukan dengan alat bantu parang atau arit untuk mencabut gulma-gulma yang tumbuh di sekitar tanaman padi.
Manyi

Tahap ketujuh Manyi. Dalam bahasa Indonesia, Manyi diartikan dengan panen. Setelah tiba waktunya memanen, masyarakat Dayak Kubin akan melakukan kegiatan Manyi, yaitu kegiatan memanen bulir-bulir padi yang telah menguning. Manyi juga dilakukan dengan cara dimulai dari sebelah kiri ke kanan. Metode itu merupakan kebalikan dari metode Nugal. Hal tersebut dimaksudkan agar proses Manyi terasa lama. Pandangan Dayak Kubin, jika Manyi terasa lama, secara otomatis hasil dari ladang tersebut banyak. Meskipun saat ini anggapan tersebut tidak dimaknai sepenuhnya seperti itu, namun pada pelaksanaannya suku Dayak Kubin masih memulai Manyi dari kiri ke kanan.

Ngirik Padi

Tahap kedelapan Ngirik Padi. Ngirik Padi ialah suatu kegiatan yang memisahkan bulir-bulir padi dari tangkai padi. Terisia mengatakan bahwa sebenarnya Ngirik Padi pada zaman dahulu sebagian besar dilakukan oleh pribadi tanpa perlu ada kegiatan Bejopai. Akan tetapi, di akhir tahun-tahun belakangan ini, Ngirik Padi juga telah mendapat tempat dalam kegiatan Bejopai, yaitu dengan bekerja sama dan juga secara bergiliran (Amit, 2020). Mengingat budaya Bejopai hanya didapati di wilayah desa saja, alat yang digunakan untuk Ngirik Padi hanya dilakukan secara manual.

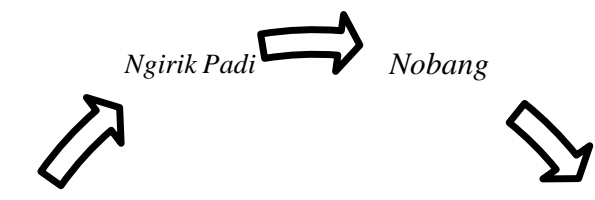

Manyi

Meladang
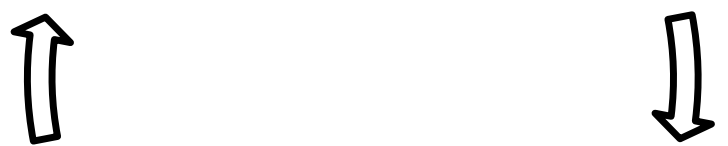

Mabau Nunu
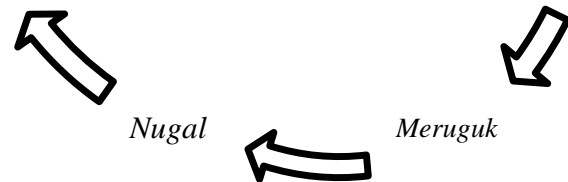

Meruguk

Gambar 1. Siklus Pelaksanaan Bejopai 


\section{Dasar Teologis Budaya Bejopai}

Banyak kisah di Alkitab yang menceritakan tentang orang-orang yang menggunakan sistem bekerja bersama-sama, terkhusus dalam Perjanjian Lama. Hal tersebut dapat dilihat dalam kisah Menara Babel (Kej. 11:1-9), kerja paksa di Mesir (Kel. 1:114), pembangunan Bait Suci di Yerusalem (1 Raj. 56), rombongan nabi yang hendak membangun rumah bagi nabi Elisa (2 Raj. 6:1-7), pembangunan kembali Bait Suci (Hagai, Ezra 3-6), pembangunan tembok Yerusalem (Neh. 3-6). Sedangkan di dalam Perjanjian Baru, konsep Bejopai digambarkan dalam perumpamaan, yaitu perumpamaan yang Yesus sampaikan tentang orang-orang upahan di kebun anggur (Mat. 20:1-15).

Namun, kisah Alkitab yang mendekati konsep Bejopai ialah kisah tentang Rut dan perumpamaan Tuhan Yesus tentang orang-orang upahan di kebun anggur. Kisah dalam kitab Rut menceritakan bahwa Rut pergi ke ladang milik Boas untuk memungut bulir-bulir jelai (yang berarti gandum) (Harrison \& Pfeiffer, 2004, p. 724), dari pagi hingga sore (Rut 2:2). Boas merupakan tuan dari ladang tersebut. Hal itu tampak dari adanya penyabit-penyabit di ladang Boas. Penyabit-penyabit juga menyebut Boas sebagai tuan mereka (Rut 2:4). Selain itu, ungkapan Boas kepada Rut, yaitu “...tetaplah dekat pengerja-pengerjaku perempuan." (ay. 8) mengindikasikan bahwa orang-orang yang bekerja di ladangnya Boas ialah orang-orang upahan. Boas merupakan orang yang kaya raya dan terpandang (Karman, 2009, p. 100). Boas juga seorang pria yang sudah tidak muda lagi, namun memiliki harta yang cukup banyak (Basuki, 2018, p. 22). Bekerja di ladang bersama-sama, bekerja dari pagi hingga sore, berkelompok (lakilaki dan perempuan), serta ada yang bekerja sebagai upahan merupakan konsep dari budaya Bejopai.

Konsep serupa juga yang terlihat dalam perumpamaan Tuhan Yesus, yang mana pada saat Yesus melayani, masyarakat yang dilayani-Nya mayoritas bekerja sebagai petani yang bercocok tanam (Karnawati, Hosana, \& Darmawan, 2019, p. 84). Namun dalam perumpamaan Yesus tersebut, konsep
Bejopai yang terlihat yaitu hanya orang upahan dan bekerja bersama-sama.

\section{Makna Kultural Budaya Bejopai dalam Suku Dayak Kubin}

Makna ialah sebuah persepsi, pikiran atau perasaan yang dialami oleh seseorang dan dapat dikomunikasikan kepada orang lain (Liliweri, 2011, p. 50). Sumanto (2015, p. 59) mengatakan bahwa makna ialah arti yang dimiliki untuk menunjukkan sebuah tanda. Dalam hal ini penulis memaparkan makna yang terkandung dalam budaya Bejopai pada suku Dayak Kubin.

\section{Penghargaan kepada Nenek Moyang}

Penghargaan kepada nenek moyang merupakan hal yang wajar dan patut diterapkan bagi semua suku. Sebagaimana yang dikatakan oleh Fardhillah (2010, p. 52) bahwa masyarakat di Aceh memaknai kesenian Tari Saman sebagai suatu wujud penghargaan terhadap hasil karya nenek moyang mereka. Hal ini juga yang dipahami oleh masyarakat Dayak Kubin dalam memaknai budaya Bejopai.

Terisia (2020) mengatakan bahwa makna dari kegiatan Bejopai ialah untuk melestarikan budaya Bejopai yang telah diturunkan oleh nenek moyang suku Dayak Kubin dan memeliharanya. Terisia juga menjelaskan bahwa pelestarian dan pemeliharaan budaya Bejopai tersebut dilakukan dengan memperkenalkannya kepada anak dan bila perlu anak diajak untuk ikut dalam kegiatan Bejopai. Pola tersebut akan terus berkelanjutan. Selain itu, alasan budaya Bejopai perlu dilestarikan ialah sebagai penghormatan kepada nenek moyang suku Dayak Kubin yang telah menemukan pola kerja yang masih relevan hingga saat ini.

Budaya Bejopai masih bertahan hingga saat ini dikarenakan kebutuhan dari masyarakat Dayak Kubin. Dengan diadakannya kegiatan Bejopai, pekerjaan ladang yang seharusnya diselesaikan dalam waktu yang lama, dapat terselesaikan dengan waktu yang relatif singkat. Hal tersebut juga yang katakan oleh Yusriadi et al. (2018, p. 21) bahwa pola kerja Bejopai 
ialah dengan membantu mengerjakan ladang orang lain bersama-sama secara bergiliran agar pekerjaan yang berat terasa ringan. Hal ini menjadi sangat penting bagi masyarakat Dayak Kubin.

\section{Kebersamaan dan Solidaritas}

Budaya Bejopai menghasilkan makna kebersamaan dan solidaritas dalam masyarakat Dayak Kubin di Desa Sungai Bakah. Alfaqi (2016, p. 113) menjelaskan bahwa solidaritas ialah suatu sikap kesetiakawanan dan kebersamaan di dalam kepentingan bersama dan juga sikap simpati terhadap suatu kelompok tertentu. Sikap kebersamaan dan kesetiakawanan inilah yang terkandung dalam budaya Bejopai. Solidaritas dan kebersamaan ini dapat melenyapkan suatu ego dalam diri masyarakat Dayak Kubin. Solidaritas juga dapat mencegah terjadinya perpecahan di dalam suku Dayak Kubin. Persatuan yang terbentuk dalam suku Dayak Kubin juga tidak membuat suku ini tertutup dengan suku lainnya. Suku Dayak Kubin tetap berpadanan dengan Pancasila. Sebagaimana yang dijelaskan oleh Rani (2017, p. 357) bahwa Pancasila mengandung nilai-nilai luhur yang mana nilai-nilai luhur tersebut menjadi dasar negara. Guna mencapai tujuan dan cita-cita bangsa serta mencegah terjadinya perpecahan bangsa, warga Indonesia harus berpegang pada nilai-nilai luhur pancasila tersebut.

Dengan adanya budaya Bejopai, masyarakat Dayak Kubin merasa adanya kebersamaan dan itu mencegah adanya perpecahan, baik sesama masyarakat Dayak Kubin maupun dengan masyarakat suku lainnya. Firman (2021) mengatakan bahwa melalui aktivitas Bejopai, masyarakat diajar untuk mengerti arti kekeluargaan. Persatuan dan kekeluargaan yang terjalin dari budaya Bejopai ini sangat kuat sehingga masyarakat Dayak Kubin yang ada di desa Sungai Bakah menjadi lebih peduli akan sesama dan mengurungkan sikap mementingkan diri sendiri.

Selain dari penjelasan di atas, budaya Bejopai dimaknai oleh masyarakat Dayak Kubin dengan adanya kebersamaan. Kebersamaan bagi masyarakat Dayak Kubin sangatlah penting. Tali persaudaraan melalui kegiatan Bejopai menjadi terbangun. Parapat dan Aritonang (2019, p. 45) mengatakan bahwa budaya sebagai tradisi dapat menjadi media untuk mempererat rasa persaudaraan antar sesama masyarakat. Selain itu, masyarakat Dayak Kubin juga belajar untuk mengatur waktu dan juga meluangkan waktu untuk bekerja dan berkumpul. Terkadang kegiatan Bejopai menjadi tolak ukur waktu angkatan tua masyarakat Dayak Kubin. Melihat ada rombongan yang pergi untuk Bejopai, itu menandakan bahwa waktu sekitar pukul 09:00 WIB. Kegiatan Bejopai juga menjadi kesempatan bagi masyarakat Dayak Kubin untuk berkumpul. Kesibukan pekerjaan pribadi baik di rumah maupun di kebun pribadi membuat masyarakat Dayak Kubin tidak memiliki waktu untuk berkumpul bersama masyarakat lainnya.

Pada saat bekerja, baik meladang, nugal, maupun mabau, biasanya masyarakat Dayak Kubin juga dalam bekerja, membentuk beberapa kelompok. Di dalam kelompok tersebut, masyarakat saling bercerita dan berbagi pengalaman. Topik yang diceritakan pun beragam mulai dari cerita humor hingga cerita pergumulan pribadi. Dari kebersamaan dan cerita tersebut, masyarakat Dayak Kubin menjadi lebih mengenal satu dengan yang lainnya. Hal penting lainnya yang bermakna pada saat Bejopai ialah masyarakat Dayak Kubin dapat saling menguatkan ketika ada masalah yang dialami oleh salah satu kelompok masyarakat Dayak Kubin. Itulah makna kebersamaan yang terbentuk dari budaya Bejopai dalam suku Dayak Kubin di Desa Sungai Bakah.

\section{Sebagai Wadah Edukasi Bagi Anak}

Tidak jarang anak remaja maupun anak muda ikut dalam Bejopai. Biasanya setelah pulang sekolah, anak diajak oleh orang tua pergi ke ladang untuk ikut Bejopai. Selain sebagai ungkapan penghargaan kepada nenek moyang yang telah menemukan dan melestarikan budaya Bejopai ini, budaya Bejopai juga dimaknai sebagai wadah atau kegiatan yang mendidik anak. Dalam skripsinya, Pertiwi (2016, p. 8) mengatakan bahwa nilai-nilai yang terkandung dalam budaya dapat mengontrol masyarakat dan juga meningkatkan moral serta akhlak. 
Demikian pula dengan budaya Bejopai sebagai wadah edukasi yang mencakup beberapa aspek seperti: aspek sosial: Anak diajarkan sejak dini agar memiliki kerpibadian dan sikap sosial yang tinggi; aspek mental: Anak dilatih agar tidak merasa rendah diri dan tidak terkejut ketika berada dalam kelompok masyarakat; aspek karakter: Dengan melihat apa yang dilakukan oleh orang yang lebih dewasa dan berpengalaman, anak kemudian dapat menirunya, anak dididik untuk belajar bekerja guna mempersiapkannya kelak sebagai pribadi yang mandiri dan bertanggungjawab. Riso (2021) mengatakan bahwa Bejopai dapat dikatakan sebagai aktivitas yang mendidik anak untuk bercocok tanam. Artinya bahwa anak diajarkan untuk bekerja dan bertanggung jawab; aspek emosional: Budaya Bejopai secara tidak langsung menumbuhkan sikap kepedulian antar satu dengan yang lain. Dengan pola kerja bergotong-royong dan bergiliran, Bejopai memberikan edukasi bagi anak untuk saling menolong dan peduli satu sama lain, dan aspek terpenting ialah; aspek spiritual: Pada saat hendak memulai bekerja dan setelah selesai bekerja, masyarakat Dayak Kubin di Desa Sungai Bakah mengawali dan mengakhirinya dengan doa. Doa yang dipanjatkan berisi permohonan agar Tuhan memberkati ladang-ladang mereka dan doa ucapan syukur atas penyertaan-Nya, baik dalam bekerja maupun dalam pencurahan berkat-Nya yang terlihat dari hasil panen dari ladang tersebut. Dengan keikutsertaan anak dalam Bejopai, anak dididik untuk selalu mengutamakan Tuhan di dalam setiap kehidupannya.

\section{Pendekatan Pemuridan Kontekstual Melalui Budaya Bejopai}

Pemuridan merupakan salah satu amanat yang Yesus berikan kepada setiap orang percaya. Gereja (orang percaya) memiliki tanggung jawab untuk memuridkan (Darmawan, 2019a, p. 152). Salah satu fungsi pemuridan ialah untuk memperlengkapi setiap individu agar bertumbuh di dalam Kristus (Daniel F. Panuntun \& Paramita, 2019, p. 106). Hutabarat (2011, p. 75) mengungkapkan bahwa pemuridan adalah suatu proses seorang Kristen mem- bagikan prinsip-prinsip firman Tuhan kepada orangorang yang baru menerima Yesus dan percaya, agar mereka dapat mengenal lebih dalam sampai pada tahap mereka dapat membagikan prinsip-prinsip kebenaran kepada orang lain. Sedangkan kontekstual ialah berhubungan dengan konteks atau pun penyesuaian dengan konteks tempat dan kebiasaan setempat. Istilah kontekstual telah digunakan secara populer dalam dunia teologi pada akhir abad ke-20. Kata ini ditambahkan pada perbendaharaan kata dalam bidang misi dan teologi sejak diperkenalkan oleh Theological Education Fund (TEF) pada tahun 1972. Ada kelompok yang mempergunakan dan mempertahankan penggunaan istilah kontekstualisasi (Tomatala, 2004, p. 17). Yusuf (2020, p. 32) mengartikan kata "kontekstual" sebagai suatu pendekatan yang dilakukan untuk memahami suatu objek dengan melihat faktor eksternal yang memengaruhi atau membentuk objek. Kadir (2013, p. 25) juga mengatakan bahwa kontekstual ialah situasi yang berhubungan atau berkaitan dengan suatu peristiwa maupun kejadian.

Dapat disimpulkan bahwa pemuridan kontekstual ialah proses pengenalan yang mendalam tentang Yesus sehingga dapat memuridkan orang lain dengan pendekatan kebudayaan setempat. Pemuridan kontekstual ialah salah satu metode pemuridan dari banyak model pemuridan yang ada. Pemuridan kontekstual merupakan salah satu model pemuridan yang praktis dan aplikatif (Daniel F. Panuntun \& Paramita, 2019, p. 107). Haryono dan Yuliati (2018, pp. 60-63) juga menerangkan bahwa karakteristik dari pemuridan sesuai konteks ialah alkitabiah, kontekstual, terfokus, dan independen. Namun pendekatan pemuridan kontekstual perlu mempertahankan prinsip-prinsip firman Tuhan, sebagaimana yang dikatakan oleh Siswanto $(2017$, p. 16) bahwa pengembangan pendekatan kontekstual dengan budaya tetap dilakukan dengan berlandaskan pada prinsip-prinsip iman Kristen. Begitu pun pemuridan sangat penting bagi suku Dayak Kubin. Melalui budaya Bejopai, pemuridan dapat dilakukan dengan baik. Berikut beberapa pendekatan pemuridan kontekstual melalui budaya Bejopai. 


\section{Pendekatan Melalui Komunikasi Persuasif}

Komunikasi persuasif ialah komunikasi yang bersifat memengaruhi pendengar agar sikap dan tindakan pendengar sesuai dengan apa yang diharapkan oleh komunikator (Deddy, 2008, p. 75). Komunikasi persuasif juga merupakan suatu komunikasi yang bertujuan untuk mengubah, memodifikasi, atau membentuk respon dari pendengar (Senjaya, 1994, p. 56). Komunikasi persuasif juga merupakan suatu perilaku yang memiliki tujuan untuk mengubah sikap atau perilaku individu maupun kelompok melalui transmisi beberapa pesan (Effendi, 1990, p. 90). Dari beberapa pendapat tokoh di atas, dapat disimpulkan bahwa komunikasi persuasif merupakan suatu aktivitas penyampaian pesan atau informasi yang meyakinkan dengan tujuan mengubah perilaku si pendengar dari nilai-nilai yang terkandung dalam pesan tersebut.

Mengingat dalam aktivitas Bejopai, masyarakat Dayak Kubin biasanya melakukan kegiatan Bejopai dan saling berdiskusi satu dengan yang lain, pendekatan pemuridan secara kontekstual dapat dilakukan melalui komunikasi persuasif. Melalui diskusi dengan orang-orang yang ikut dalam kegiatan Bejopai, seseorang dapat membangun komunikasi yang bersifat persuasif dengan menanamkan nilai-nilai kebenaran. Nilai-nilai kebenaran inilah yang kemudian dapat mengubah karakter dan pemahaman seseorang sehingga terus bertumbuh di dalam Kristus. Pendekatan ini seyogyanya dilakukan terus-menerus. Bersamaan dengan kegiatan Bejopai yang dilakukan hampir setiap hari, komunikasi persuasif dengan upaya memuridkan seseorang juga dilakukan secara konsisten dan teratur. Sebagaimana yang dikatakan oleh Oei (2017, p. 74) bahwa upaya pemuridan membutuhkan kekonsistenan dan fokus yang tahan uji terhadap pesan yang disampaikan dari Alkitab. Dengan melakukan pemuridan melalui komunikasi persuasif secara konsisten, itu akan membuahkan hasil.

\section{Pendekatan Melalui Pola Bekerja Sambil Bercerita}

Willis dan Snowden (2017, p. 28) mengungkapkan bahwa pola bercerita-Alkitab dapat memak- simalkan kerja pancaindera seseorang yang Allah berikan sehingga dapat mengingat firman Tuhan dengan lebih baik. Yesus juga dalam pelayanan-Nya banyak menggunakan metode bercerita dalam mengajar dengan menggunakan perumpamaan. Yesus juga mengambil ilustrasi dari kisah kehidupan masya-rakat sekitar. Yesus mengambil ilustrasi dari pengalaman hidup para pendengar agar mereka dapat paham apa yang Ia sampaikan (Douglas, 2003, p. 2274). Sebagaimana yang dijelaskan oleh Harming dan Katarina (2019, p. 118) bahwa dalam berkontekstual, perlu menggunakan media yang ada di dalam budaya tersebut. Dalam mengajar pun Yesus tidak hanya berfokus kepada satu orang saja, Yesus juga mengajar melalui bercerita kepada banyak orang (Mat.13:1-52).

Pola bekerja suku Dayak Kubin dalam kegiatan Bejopai ialah pola bekerja sambil bercerita (lih. Pembahasan Kebersamaan dan Solidaritas). Pola bekerja sambil bercerita ini yang kemudian dapat gunakan sebagai pendekatan pemuridan secara kontekstual. Sebagaimana masyarakat Dayak Kubin di Desa Sungai bakah memiliki kebiasaan bercerita tentang kehidupan sehari-hari dan bersenda-gurau saat Bejopai, momen tersebut dapat digunakan de-ngan diskusi kebenaran firman Tuhan, PA praktis, dan bahkan masuk kepada konseling pastoral. Bahasa yang digunakan juga tentunya disesuaikan dengan konteks pendengar, agar pemahaman Alkitab dapat dimengerti secara kontekstual (Daniel Fajar Panuntun, 2019, p. 5). Melalui momen-momen yang diisi dengan cerita kebenaran firman Tuhan menambahkan rasa solidaritas yang penuh makna. Pengajaran tersebut juga perlu dilakukan berulang-ulang agar informasi yang disampaikan dapat direkam dan disimpan (Darmawan, 2019b, p. 26). Kebiasaan buruk dari masyarakat yang terkadang meng-gosip-kan orang lain, perlahan dapat diubah dengan diskusi nilai-nilai rohani, tidak hanya tentang Alkitab, tetapi juga kisah pengalaman hidup yang memberkati satu dengan yang lain.

\section{Memuridkan Untuk Memuridkan}

Selain untuk membawa seseorang bertumbuh di dalam Kristus, tujuan akhir dari pemuridan kon- 
tekstual, sebagaimana yang diungkapkan oleh Haryono dan Yulianti (2018, p. 62) ialah untuk bermultiplikasi sehingga orang-orang yang dimuridkan dapat memuridkan dan menjadi murid untuk hidup sama-sama bertumbuh dalam Kristus. Kemudian $\mathrm{Hu}$ tabarat (2011, p. 76) juga mengungkapkan bahwa tujuan utama orang dewasa dalam Kristus ialah untuk memperkenalkan Kristus pada orang lain. Pernyataan tersebut juga selaras dengan Amanat Agung Tuhan Yesus dalam Injil Matius 28:19-20. Hal tersebut menunjukkan bahwa multiplikasi itu sangatlah penting dalam kekristenan.

Bagian ini ingin menjelaskan bahwa pemuridan secara kontekstual terhadap masyarakat Dayak Kubin di Desa Sungai Bakah melalui budaya Bejopai ialah pemuridan yang dilakukan tidak hanya melalui perkataan yang memberikan pemahaman, tetapi juga diwujudkan melalui tindakan langsung, yaitu masyarakat Dayak Kubin di Desa Sungai Bakah juga dapat menjadi seseorang yang dapat memuridkan orang lain. Sebagaimana pembahasan sebelumnya yang mengatakan bahwa anak remaja dan pemuda juga ikut serta dalam kegiatan Bejopai, penulis memanfaatkan kondisi ini untuk melakukan pemuridan. Memuridkan orang-orang dewasa dan memperlengkapinya, kemudian orang-orang dewasa tersebut memuridkan

\section{DAFTAR RUJUKAN}

Alfaqi, M. Z. (2016). Memahami Indonesia Melalui Perspektif Nasionalisme, Politik Identitas, Serta Solidaritas. Jurnal Ilmiah Pendidikan Pancasila Dan Kewarganegaraan, 28(2).

Amit, T. (2020, November 3). Wawancara oleh Penulis, Sungai bakah, Kalimantan Barat [Telepon Seluler].

Badan Pusat Statistik Kabupaten Melawi. (2015, November 5).

Basuki, P. M. (2018). Pemahaman Kata GO'EL Dalam Kitab Rut. Jurnal Teologi \& Pelayanan KERUSSO, 3(2), 20-24. https://doi.org/10.33856/kerusso.v3i2.94 anak remaja dan pemuda dengan menanamkan nilainilai kristiani, menjadi teladan, dan mendidik mereka dalam kebenaran. Proses ini tentunya dapat dilakukan dengan perlahan dan konsisten.

\section{KESIMPULAN}

Budaya Bejopai merupakan budaya yang masih bertahan hingga saat ini karena selain kebutuhan masyarakat Dayak Kubin, budaya Bejopai juga menciptakan suatu kebersamaan yang mendalam. Hal tersebut merupakan faktor yang membuat budaya Bejopai masih relevan hingga saat ini. Selain itu, Budaya Bejopai juga menciptakan peluang bagi pelayanan pemuridan. Makna kebersamaan yang digambarkan melalui bercerita akan pergumulan maupun cerita candaan lainnya merupakan peluang dalam melakukan pemuridan. Melalui pola bekerja sambil bercerita, pemuridan secara kontekstual dapat dilakukan. Pemuridan dengan pola bercerita tentang kebenaran firman Tuhan di dalam kelompok kecil dapat dijadikan pendekatan kontekstual bagi suku Dayak Kubin. Pendekatan pemuridan secara kontekstual juga dilakukan dengan terstruktur mengingat kegiatan Bejopai dilakukan hampir setiap hari. Meski cenderung lama, pola bercerita dalam kelompok kecil dapat menjadi efektif jika terus-menerus dilakukan.

Coomans, M. (1987). Manusia Dayak: Dahulu, Sekarang, Masa Depan. Jakarta: Gramedia Pustaka Utama.

Darmadi, H. (2017). Dayak, Asal-Usul dan Penyebarannya di Bumi Borneo (1). Sosial Horizon: Jurnal Pendidikan Sosial, 3(2), 322340.

Darmawan, I. P. A. (2019a). Jadikanlah Murid: Tugas Pemuridan Gereja Menurut Matius 28:18-20. Evangelikal: Jurnal Teologi Injili dan Pembinaan Warga Jemaat, 3(2), 144. https://doi.org/10.46445/ejti.v3i2.138

Darmawan, I. P. A. (2019b). Pembelajaran Memorisasi Dalam Ulangan 6:6-9. EPIGRAPHE: Jurnal Teologi Dan Pelayanan 
Kristiani,

$3(1)$,

$21-27$.

https://doi.org/10.33991/epigraphe.v3i1.50

Deddy, M. (2008). Ilmu Komunikasi Suatu Pengantar. Bandung: PT Remaja Rosdakarya.

Douglas, J. D. (2003). Ensiklopedia Alkitab Masa Kini Jilid II: M-Z. Jakarta: Yayasan Komunikasi Bina Kasih.

Effendi, O. U. (1990). Komunikasi: Teori dan raktik. Bandung: PT Remaja Rosdakarya.

Fardhillah, N. (2010). Mengenal Kesenian Nasional II Tari Saman. Semarang: ALPRIN.

Firman. (2021, January 18). Wawancara Penulis dengan Salah Satu Pemuda Desa Sungai Bakah [WhatsApp].

Gulo, D. M., Susanto, S., \& Gultom, J. M. P. (2019). Kajian Misi Kontekstual Terhadap Spiritualitas Dalam Budaya: Budaya Mabak-Sabek di Dusun Gun Jemak-Kalimantan Barat. 4(2), 77-84.

Halim, M. (2000). Gereja di Tengah-Tengah Perubahan Zaman. Malang: Gandum Mas.

Harming. (2017). Bergunuk Mahasiswa Suku Dayak

Sebagai Pendekatan Konseling Solidaritas di

Sekolah Tinggi Teologi Simpson Ungaran. Universitas Kristen Satya Wacana, Salatiga.

Harming, H., \& Katarina, K. (2019). Strategi Pelayanan Lintas Budaya Berdasarkan Markus 4:1-34. Evangelikal: Jurnal Teologi Injili Dan Pembinaan Warga Jemaat, 3(1), 113-121. https://doi.org/10.46445/ejti.v3i1.130

Harrison, E. F., \& Pfeiffer, C. F. (2004). Tafsiran Alkitab Wycliffe Volume 1. Malang: Gandum Mas.

Haryono, T., \& Yuliati. (2018). Pemuridan Kontekstual. Surakarta: Yayasan Gamaliel.

Herwinasastra, H. (2019). Budaya Betangkant Anak Dalam Suku Dayak Keninjal Sebagai Upaya Kontektualisasi Kasih Allah. Evangelikal: Jurnal Teologi Injili dan Pembinaan Warga Jemaat, 3(2), 200-207. https://doi.org/10.46445/ejti.v3i2.147

Hesselgrave, D. J., \& Rommen, E. (2015). Kontekstualisasi Makna, Metode, dan Model. Jakarta: BPK Gunung Mulia.
Hutabarat, H. N. (2011). Mentoring dan Pemuridan. Bandung: Kalam Hidup.

Jr, A. T. W., \& Snowden, M. (2017). Truth That Sticks (Kebenaran yang Melekat): Menyampaikan Kebenaran yang Melekat dengan Menceritakan Alkitab. Katalis Media \& Literature - Yayasan Gloria.

Kadir, A. (2013). Konsep Pembelajaran Konseptual di Sekolah. Dinamika Ilmu, 13(1).

Karman, Y. (2009). Tafsiran Alkitab: Kitab Rut. Jakarta: BPK Gunung Mulia.

Karnawati, K., Hosana, H., \& Darmawan, I. P. A. (2019). Lingkungan Proses Pembelajaran Yesus. Veritas Lux Mea (Jurnal Teologi Dan Pendidikan Kristen), 1(2), 76-89.

Liliweri, A. (2011). Komunkasi Serba Ada Serba Makna. Jakarta: Prenada Media Group.

Maunati, Y. (2004). Identitas Dayak. Yogyakarta: Lkis Pelangi Aksara.

Moleong, L. J. (2018). Metodologi Penelitian Kualitatif. Bandung: Remaja Rosdakarya.

Oei, A. W. (2017). Khotbah yang Kontekstual: Memuridkan Para Pengkhotbah untuk Memuridkan Jemaat. Jurnal Theologia Aletheia, 19(12), 69-90.

Paiso, R. (2021, January 18). Wawancara Penulis dengan Salah Satu Kepala Keluarga Masyarakat Desa Sungai Bakah [WhatsApp].

Panuntun, Daniel F., \& Paramita, E. (2019). Hubungan Pembelajaran Alkitab Terhadap Nilai-Nilai Hidup Berbangsa dalam Pemuridan Kontekstual (Kelompok Tumbuh Bersama Kontekstual). Jurnal Gamaliel: Teologi Praktika, 1(2), 104-115.

Panuntun, Daniel Fajar. (2019). Tinjauan Alkitabiah Pemuridan Kontekstual Paulus Kepada Jemaat Korintusdan Relevansinya bagi Pemuridan Di Era Postmodern. Jurnal Umpuran Mali', 6(1), $1-11$.

Parapat, L. H., \& Aritonang, D. R. (2019). Buku Ajar Sastra \& Budaya Lokal Untuk Perguruan Tinggi. Ponorogo, Jawa Timur: Uwais Inspirasi Indonesia. 
Pertiwi, D. O. (2016). Pengembangan Buku Pengayaan Menyusun Teks Eksposisi Berbasis Kearifan Lokal untuk Peserta Didik Sekolah Menengah Pertama (SMP). Universitas Negeri Semarang, Semarang.

Pram. (2013). Suku Bangsa Dunia dan Kebudayaannya. Jakarta: Cerdas Interaktif.

Rani, N. P. (2017). Reaktualisasi Pancasila Sebagai Upaya Pencegahan Radikalisme. Fikri: Jurnal Kajian Agama, Sosial Dan Budaya, 2(3), 345378.

Senjaya, S. D. (1994). Teori Komunikasi. Jakarta: Universitas Terbuka.

Siswanto, K. (2017). Perjumpaan Injil dan Tradisi Jawa Timuran Dalam Pelayanan Misi Kontekstual. Evangelikal: Jurnal Teologi Injili Dan Pembinaan Warga Jemaat, 1(1), 61-66.

Sumanto. (2015). Makna Simbolis Gambar AnakAnak. Malang: Penerbit Gunung Samudera.
Susanto, S. E. (2016). Penyelesaian Hak Asuh Anak Setelah Perceraian Menurut Adat Masyarakat Dayak Kubin di Desa Nangaraya Kecamatan Belimbing Hulu Kabupaten Melawi. Universitas Tanjung Pura, Pontianak.

Tanjung, R., Ritonga, T., \& Siregar, E. Y. (2021). Analisis Minat Belajar Siswa dalam Pembelajaran Daring Pada Masa Pandemi Covid-19 di Desa Ujung Batu Barus. Jurnal MathEdu, 4(1), 88-96.

Tomatala, Y. (2004). Yesus Kristus Juruselamat Dunia. Jakarta: YT Leadership Foundations. Yusriadi, Y., Ruslan, I. R. I., \& Hariansyah, H. (2018). Narasi Kebahan Sebagai Resolusi Konflik Pada Masyarakat Nanga Pinoh, Melawi. Jurnal SMART (Studi Masyarakat, Religi, dan Tradisi), 4(1), 15-26. https://doi.org/10.18784/smart.v4i1.583

Yusuf, M. (2020). Relasi Teks dan Konteks. Yogyakarta: Indie Book Corner. 